Review

\title{
Vitamin D: Deficiency, Sufficiency and Toxicity
}

Fahad Alshahrani ${ }^{1}$ and Naji Aljohani ${ }^{2,3,4, *}$

1 Department of Medicine, King Abdulaziz Medical City, Riyadh 14611, Saudi Arabia;

E-Mail: fahad_alshahrani@yahoo.com

2 Specialized Diabetes and Endocrine Center, King Fahad Medical City, Riyadh 59046, Saudi Arabia; E-Mail: najijohani@gmail.com

3 Faculty of Medicine, King Saud bin Abdulaziz University for Health Sciences, Riyadh 22490, Saudi Arabia

4 Prince Mutaib Chair for Biomarkers of Osteoporosis, College of Science, King Saud University, Riyadh 11451, Saudi Arabia

* Author to whom correspondence should be addressed; E-Mail: najijohani@gmail.com; Tel.: +966-1-467-5939; Fax: +966-1-467-5931.

Received: 6 May 2013; in revised form: 21 August 2013 / Accepted: 27 August 2013 /

Published: 13 September 2013

\begin{abstract}
The plethora of vitamin D studies over the recent years highlight the pleomorphic effects of vitamin D outside its conventional role in calcium and bone homeostasis. Vitamin D deficiency, though common and known, still faces several challenges among the medical community in terms of proper diagnosis and correction. In this review, the different levels of vitamin D and its clinical implications are highlighted. Recommendations and consensuses for the appropriate dose and duration for each vitamin D status are also emphasized.
\end{abstract}

Keywords: vitamin D; vitamin D deficiency; vitamin D toxicity

\section{Introduction}

Vitamin D plays an essential role in the regulation of metabolism, calcium and phosphorus absorption of bone health. However, the effects of vitamin D are not limited to mineral homeostasis and skeletal health maintenance. The presence of vitamin D receptors (VDR) in other tissue and organs suggest that vitamin D physiology extends well above and beyond bone homeostasis [1]. Additionally, 
the enzyme responsible for the conversion of $25[\mathrm{OH}] \mathrm{D}$ to its biologically active form [Vitamin D $\left.\left(1,25[\mathrm{OH}]_{2} \mathrm{D}\right)\right]$ has been identified in other tissues aside from kidneys [2,3], and that extra renal synthesis of $1,23[\mathrm{OH}]_{2} \mathrm{D}$ may be equally important in regulating cell growth and differentiation via paracrine or autocrine regulatory mechanisms [4].

The mechanism of action of vitamin $\mathrm{D}_{3}$ through its hormonal form, dihydroxyvitamin $\mathrm{D}_{3}$, involves a nuclear VDR that regulates the transcription of several target genes in a variety of vitamin D target cells that are primarily involved in the calcium homeostasis of cell differentiation [5]. Hypervitaminosis D occurs when pharmacologic doses of vitamin D are consumed for prolonged periods of time or from a single megadose translating to a large increase in circulating $25[\mathrm{OH}] \mathrm{D}$ concentrations [6].

\section{Vitamin D Metabolism}

Vitamin $\mathrm{D}$ has two distinct forms: vitamins $\mathrm{D}_{2}$ and $\mathrm{D}_{3}$. Vitamin $\mathrm{D}_{2}$ is a 28-carbon molecule derived from ergosterol (a component of fungal cell membranes), while vitamin $\mathrm{D}_{3}$ is a 27 -carbon derived from cholesterol [7]. UV-B irradiation of skin triggers photolysis of 7-dehydrocholesterol (pro-vitamin $D_{3}$ ) to pre-vitamin $D_{3}$, which is rapidly converted to vitamin $D_{3}$ by the skin's temperature. Vitamin $D$ $\left(\mathrm{D}_{2}\right.$ and $\left.\mathrm{D}_{3}\right)$ from the skin and diet undergo two sequential hydroxylations: first in the liver (25[OH]D) and then in the kidney, leading to its biologically active form 1,25-dihydroxyvitamin $\mathrm{D}\left(1,25[\mathrm{OH}]_{2} \mathrm{D}\right)[8]$. Table 1 shows the nomenclature for vitamin D precursors and metabolites.

Table 1. Nomenclature of vitamin D precursors and metabolites.

\begin{tabular}{|c|c|c|c|}
\hline Common Name & Clinical Name & Abbreviation & Comments \\
\hline 7-Dehydrocholesterol & Pro-vitamin $\mathrm{D}_{3}$ & 7DHC & Lipid in cell membranes \\
\hline Cholecalciferol & Pre-vitamin $\mathrm{D}_{3}$ & & Photosynthesized in skin or diet \\
\hline Ergocalciferol & Pre-vitamin $\mathrm{D}_{2}$ & & $\begin{array}{c}\text { Obtained from diet. Equivalent to } \\
\text { vitamin } \mathrm{D}_{3} \text { as precursor for active } \\
\text { vitamin } \mathrm{D}\end{array}$ \\
\hline Calcidiol & 25-Hydroxyvitamin D & $25[\mathrm{OH}] \mathrm{D}$ & Best reflects vitamin D status \\
\hline Calcitriol & 1,25-Dihydroxvitamin D & $1,25[\mathrm{OH}] \mathrm{D}_{2}$ & $\begin{array}{c}\text { Active form of vitamin D, tightly } \\
\text { regulated }\end{array}$ \\
\hline
\end{tabular}

The $1,25[\mathrm{OH}]_{2} \mathrm{D}$ ligand binds with high affinity to vitamin $\mathrm{D}$ receptors (VDRs), which then increases intestinal absorption of both calcium and phosphorus. In addition, vitamin D is actively involved in bone formation, resorption, mineralization, and in maintenance of neuromuscular function. Circulating $1,25[\mathrm{OH}]_{2} \mathrm{D}$ inhibits serum parathyroid hormone (PTH) levels by negative feedback mechanism and by increased serum calcium levels. It also regulates bone metabolism through activation of the VDRs found in osteoblasts, releasing biochemical signals and leading to the formation of mature osteoclasts [9].

In a low vitamin $\mathrm{D}$ state, the small intestine can absorb approximately $10 \%-15 \%$ of dietary calcium. When adequate however, intestinal absorption of dietary calcium rises to approximately $30 \%-40 \%[9,10]$. Hence, low vitamin D levels $(25[\mathrm{OH}] \mathrm{D})$ may lead to insufficient calcium absorption, and this has clinical implications not only for bone health but also for most metabolic functions. The 
increase in PTH restores calcium homeostasis by increasing tubular reabsorption of calcium in the kidney, increasing bone calcium mobilization and enhancing $1,25[\mathrm{OH}]_{2} \mathrm{D}$ production [10].

\section{Optimum 25[OH]D Levels}

The vitamin D level needed to optimize intestinal calcium absorption ( $34 \mathrm{ng} / \mathrm{mL})$ is lower than the level needed for neuromuscular performance $(38 \mathrm{ng} / \mathrm{mL})[11,12]$. Experts however believe that the lower limit of adequate 25[OH]D levels should be $30 \mathrm{ng} / \mathrm{mL}$ [13]. Still others recommend a lower limit of $40 \mathrm{ng} / \mathrm{mL}$, since impaired calcium metabolism due to low serum 25[OH]D levels may trigger secondary hyperparathyroidism, increased bone turnover and progressive bone loss [14,15].

The proposed 25[OH]D cut-off for optimum skeletal health is the level that reduces PTH to a minimum and increases calcium absorption to its maximum [11,16]. Several studies have shown that PTH levels plateau at a minimum steady-state level as serum 25[OH]D levels approach and rise above approximately $30 \mathrm{ng} / \mathrm{mL}$ (75 nmol/L) [16-18]. The established consensus of several vitamin D cut-offs is presented in Table 2 [18-20]. It is noteworthy, however, that there is a continued debate and exchange of knowledge with respect to the optimum cut-off for $25(\mathrm{OH}) \mathrm{D}$.

Table 2. Diagnostic Cut-Offs of levels of serum 25[OH]D.

\begin{tabular}{ccc}
\hline $\mathbf{2 5}[\mathbf{O H}]$ Level $(\mathbf{n g} / \mathbf{m L})$ & $\mathbf{2 5}[\mathbf{O H}] \mathbf{D}$ Level $(\mathbf{n m o L} / \mathbf{L})$ & Laboratory Diagnosis \\
\hline$<20$ & $<50$ & Deficiency \\
$20-32$ & $50-80$ & Insufficiency \\
$54-90$ & $135-225$ & Normal in sunny countries \\
$>100$ & $>250$ & Excess \\
$>150$ & $>325$ & Intoxication \\
\hline
\end{tabular}

\section{Measurements of $25[\mathrm{OH}] \mathrm{D}$ versus $1,25[\mathrm{OH}]_{2} \mathrm{D}_{3}$}

The clinical advantages of choosing $25[\mathrm{OH}] \mathrm{D}$ instead of calcitriol as a marker for vitamin D status has been listed by Rajasree et al. [21]. First, 25[OH]D has the highest concentration of all vitamin D metabolites. Second, its levels remain stable for almost two weeks. Lastly, vitamin D toxicity is thought to be a function of $25[\mathrm{OH}] \mathrm{D}$ instead of calcitriol. It has been observed that serum $25[\mathrm{OH}] \mathrm{D}$ is the best indicator of vitamin D status among individuals without kidney disease [22]. Furthermore, 25[OH]D in large amounts can replace calcitriol to stimulate bone calcium metabolism [23]. Although nephrectomy abolishes a response to physiological dose of 25[OH]D, a large dose (1000 fold) of $25[\mathrm{OH}] \mathrm{D}$ can stimulate intestinal calcium absorption and bone calcium metabolism in nephrectomized rats [24]. Hughes et al., studied vitamin D intoxication in two human patients with normal kidney function and showed that both patients had 16-fold above normal concentrations of plasma 25[OH]D levels $(500-600 \mathrm{ng} / \mathrm{mL})$, while $1,25[\mathrm{OH}] \mathrm{D}_{2} \mathrm{D}_{3}$ plasma concentrations were only modestly elevated (40-56 pg/mL) [25]. Differences in calcidiol versus calcitriol are presented in Table 3. 
Table 3. Calcidiol versus Calcitriol.

\begin{tabular}{|c|c|c|}
\hline Metabolite function & $25[\mathrm{OH}] \mathrm{D}$ & $1,25[\mathrm{OH}]_{2} \mathrm{D}_{3}$ \\
\hline Nutritional Status & Best indicator & $\begin{array}{c}\text { Does not indicate nutritional } \\
\text { status }\end{array}$ \\
\hline Half life & $>15$ days & $<15 \mathrm{~h}$ \\
\hline Stability in serum & Stable & Unstable \\
\hline Hypovitaminosis D & Indicative (low) & $\begin{array}{c}\text { Non-indicative } \\
\text { (normal to elevated) }\end{array}$ \\
\hline Hypervitaminosis D & Indicative (elevated) & $\begin{array}{c}\text { Non-indicative (low to normal or } \\
\text { mild elevated) }\end{array}$ \\
\hline Calcium regulation & $\begin{array}{c}\text { Possible under } \\
\text { non-physiological conditions }\end{array}$ & $\begin{array}{c}\text { Tight under } \\
\text { physiological conditions }\end{array}$ \\
\hline PTH regulation & Depends on vitamin D status & Tight \\
\hline DBP binding & $\begin{array}{l}\text { High affinity (releases the free } \\
\text { metabolite once DBP is saturated }\end{array}$ & $\begin{array}{l}\text { Low affinity to exert the } \\
\text { physiological function }\end{array}$ \\
\hline VDR binding & $\begin{array}{l}\text { Strongest among metabolite other } \\
\text { than calcitriol }\end{array}$ & $\begin{array}{l}\text { High affinity to elicit the } \\
\text { biological function }\end{array}$ \\
\hline
\end{tabular}

Note: VDR: vitamin D receptor; DBP: vitamin D binding protein; PTH: parathyroid hormone.

\section{Supplementation of Vitamin $D_{2}$ versus Vitamin $D_{3}$}

Multiple preparations of vitamin D and its metabolites are commercially available for supplement use. The two most common supplements are ergocalciferol (vitamin $\mathrm{D}_{2}$ ) and cholecalciferol (vitamin $\mathrm{D}_{3}$ ). Some studies [26,27], but not all [28], suggest that vitamin $\mathrm{D}_{3}$ increases serum 25[OH]D more efficiently than vitamin $\mathrm{D}_{2}$. A large, single dose of vitamin $\mathrm{D}_{2}$ does not last longer than a large dose of $\mathrm{D}_{3}$. In a study conducted by Armas et al., [27], subjects were given one dose of 50,000 IU of either vitamin $\mathrm{D}_{2}$ or vitamin $\mathrm{D}_{3}$. Vitamin $\mathrm{D}_{2}$ was absorbed just as well as vitamin $\mathrm{D}_{3}$, yet blood levels of $25[\mathrm{OH}] \mathrm{D}$ started dropping rapidly after 3 days among subjects given vitamin $\mathrm{D}_{2}$ whereas those on vitamin $\mathrm{D}_{3}$ sustained high levels for two weeks before dropping gradually.

A daily dose of $4000 \mathrm{IU}$ of vitamin $\mathrm{D}_{3}$ for two weeks was observed to be 1.7 times more effective in raising 25[OH]D levels than $4000 \mathrm{IU}$ of vitamin $\mathrm{D}_{2}$ [26]. On the other hand, Holick et al. found that a daily dose of $1000 \mathrm{IU}$ of vitamin $\mathrm{D}_{2}$ over 11 weeks duration increased 25[OH]D levels from 42 to $67 \mathrm{nmoL} / \mathrm{L}$ (16.9 to $26.8 \mathrm{ng} / \mathrm{mL}$ ) [28]. Consequently, vitamin $\mathrm{D}_{3}$ levels also increased from 49 to $72 \mathrm{nmoL} / \mathrm{L}$ (19.6 to $28.9 \mathrm{ng} / \mathrm{mL})$. It took 6 weeks for 25[OH]D levels to plateau on that regimen. In another study, Glendenning et al. compared 1000 IU of $\mathrm{D}_{2}$ versus $\mathrm{D}_{3}$ in patients who had vitamin $\mathrm{D}$ insufficiency with subsequent hip fractures. After three months, those who were supplemented with $\mathrm{D}_{3}$ had a $31 \%-52 \%$ greater increase in $25[\mathrm{OH}] \mathrm{D}$ levels than those supplemented with $\mathrm{D}_{2}$. However, parathyroid hormone levels did not differ between groups [29].

In children, Gordon et al., assigned 40 infants and toddlers with vitamin D deficiency to one of three regimens (2000 IU oral vitamin $\mathrm{D}_{2}$ daily, 50,000 IU vitamin $\mathrm{D}_{2}$ weekly or $2000 \mathrm{IU}$ vitamin $\mathrm{D}_{3}$ daily) for 6 weeks. At the end of the trial, 25[OH]D levels increased from 42.5 to $90 \mathrm{nmoL} / \mathrm{L}$ and there were no significant differences between treatment groups [30].

In terms of bioavailability, Biancuzzo et al., tested changes in 25[OH]D status from a daily dose of 1000 IU of vitamin $D_{2}$ or $D_{3}$ from either calcium-fortified orange juice with vitamin $\mathrm{D}$ or supplement 
capsules for 11 weeks. The average $25[\mathrm{OH}] \mathrm{D}$ levels of all groups $\left(\mathrm{D}_{2}\right.$ from orange juice, $\mathrm{D}_{2}$ from capsules, $D_{3}$ from orange juice, $D_{3}$ from capsules) went up to about $25 \mathrm{nmoL} / \mathrm{L}$ with no significant differences between groups [31].

Treatment for most studies found $\mathrm{D}_{2}$ to be less effective than $\mathrm{D}_{3}$, whereas in studies finding them equally effective, the treatment was daily amounts between 400 and 2000 IU [32]. Houghton and Vieth indicated that vitamin $\mathrm{D}_{3}$ is the most potent form of vitamin $\mathrm{D}$ in all primate species, including humans, owing to the diminished binding of vitamin $\mathrm{D}_{2}$ metabolites to DBP in plasma [33]. They also confirmed the finding of Hollick [34], which indicated that the difference in binding capacity is potentially explained by the presence of a methyl group at carbon- 24 position on the $\mathrm{D}_{2}$ molecule. The different hydroxylation sites of two forms of vitamin D leads to the production of unique biologically active metabolites. Based on this, the 24-hydroxylation after the 25-hydroxylation results in the formation of $1,24,25[\mathrm{OH}]_{3} \mathrm{D}_{2}$ and the deactivation of vitamin $\mathrm{D}_{2}$ molecule. On the other hand, the vitamin $\mathrm{D}_{3}$ metabolite $1,24,25[\mathrm{OH}]_{3} \mathrm{D}_{3}$ must undergo an additional side chain oxidation to be biologically deactivated [35]. Interestingly, $1,24,25[\mathrm{OH}]_{3} \mathrm{D}_{3}$ has the ability to bind VDR with $\sim 40 \%$ capacity higher than with $1,25[\mathrm{OH}]_{2} \mathrm{D}_{3}[36]$.

\section{Candidates for Calcidiol (25-OHD) Measurements}

The best indicator of vitamin D status is 25-OHD because it reflects cutaneous and dietary intake, not to mention it is the major circulating form of vitamin D [37]. While there are many established causes of vitamin D deficiency, as listed in Table 4, screening for the general population warrants further investigation. The United States Preventive Services Task Force (USPSTF) did not comment for or against routine screening for vitamin D deficiency. One approach is to consider serum testing in patients at high risk for vitamin D deficiency, and treating without testing those at a lower risk [38]. Just recently, a statement from Osteoporosis Canada suggested that based on clinical suspicion for vitamin D insufficiency and its complications the clinical approach can take into account three settings (Table 5).

Table 4. Major causes of vitamin D deficiency [13].

\begin{tabular}{cc}
\hline Causes & Example \\
\hline Reduced skin synthesis & $\begin{array}{c}\text { Sunscreen, skin pigment, season/time of day, aging } \\
\text { Cystic fibrosis, celiac disease, Crohn's disease, } \\
\text { gastric bypass, medications that reduce } \\
\text { cholesterol absorption }\end{array}$ \\
Increased sequestration & Obesity (BMI $>$ 30) \\
Increased catabolism & Anti-convulsant, glucocorticoid \\
Breastfeeding & Exclusively without vitamin D supplementation \\
Decreased synthesis of 25-hydroxyvitamin D & Hepatic failure \\
Increased urinary loss of 25-hydroxyvitmain D & Nephrotic proteinuria \\
Decreased synthesis of 1,25-dihydroxyvitmain D & Chronic renal failure \\
Inherited disorders & Vitamin D resistance \\
\hline
\end{tabular}


Table 5. Approach to vitamin D correction [39].

\begin{tabular}{|c|c|c|}
\hline Risk Category & Action & Level of Evidence \\
\hline Low: & & \\
\hline Adult $<50$ years & 400-1000 IU & Level 3 \\
\hline $\begin{array}{l}\text { Without comorbid conditions } \\
\text { affecting vitamin } \mathrm{D} \text { absorption } \\
\text { or action }\end{array}$ & $\begin{array}{c}\text { No calcidiol } \\
\text { measurement required }\end{array}$ & Evidence grade D \\
\hline $\begin{array}{c}\text { Moderate: } \\
\text { Adult }>50 \text { years } \\
\text { With or without osteoporosis } \\
\text { but without comorbid conditions } \\
\text { that affect vitamin D absorption } \\
\text { or action }\end{array}$ & $\begin{array}{l}\qquad 800-2000 \text { IU } \\
\text { Calcidiol measurement in initial } \\
\text { assessment but if therapy for } \\
\text { osteoporosis is prescribed, } \\
\text { calcidiol should be measured } \\
\text { after three to four months, of an } \\
\text { adequate dose. }\end{array}$ & $\begin{array}{c}\text { Level } 2 \\
\text { Evidence grade B } \\
\text { Level } 3 \\
\text { Evidence grade D }\end{array}$ \\
\hline $\begin{array}{c}\text { High: } \\
\text { Co-morbid conditions that affect } \\
\text { vitamin D absorption or action } \\
\text { and/or recurrent fractures } \\
\text { or bone loss despite } \\
\text { osteoporosis treatment }\end{array}$ & $\begin{array}{l}\text { Calcidiol should be measured } \\
\text { and supplementation based on } \\
\text { the measured value. }\end{array}$ & $\begin{array}{c}\text { Grade B } \\
\text { Recommendation }\end{array}$ \\
\hline
\end{tabular}

\section{Vitamin D Correction}

In patients with normal absorptive capacity, for every $40 \mathrm{IU} /$ day $(1 \mu \mathrm{g} / \mathrm{day})$ of vitamin $\mathrm{D}_{3}$, serum 25(OH)D concentrations increase by approximately 0.3 to $0.4 \mathrm{ng} / \mathrm{mL}(0.7$ to $1.0 \mathrm{nmol} / \mathrm{L})$ [40]. Largest increments are seen in patients with the lowest starting $25(\mathrm{OH}) \mathrm{D}$ level, but subsequently declines as 25(OH)D concentration reaches $40 \mathrm{ng} / \mathrm{mL}(100 \mathrm{nmol} / \mathrm{L})$ [41]. Nutritional deficiency (25OHD < $50 \mathrm{nmol} / \mathrm{L}$ ) requires initial treatment with 50,000 units of vitamin $\mathrm{D}_{2}$ or vitamin $\mathrm{D}_{3}$ orally once per week for 6-8 weeks, and then 800 to $1000 \mathrm{IU}$ of vitamin $\mathrm{D}_{3}$ orally thereafter [42]. Intramuscular cholecalciferol $(300,000 \mathrm{IU})$ in one or two doses per year is also an option for increasing serum 25 OHD level [43].

Nutritional insufficiency ( $25 \mathrm{OHD} 50-75 \mathrm{nmol} / \mathrm{L}$ ) requires treatment with 800 to $1000 \mathrm{IU}$ of vitamin $\mathrm{D}_{3}$ daily. This intake will bring the average adult's vitamin $\mathrm{D}$ status to $7 \mathrm{nmol} / \mathrm{L}$ higher over a three-month period. Still, many individuals might need higher doses. In malabsorptive states, oral dosing and duration of treatment is dependent on the individual patient's on vitamin $\mathrm{D}$ absorptive capacity. High doses of vitamin D (10,000 to 50,000 IU daily) may be necessary for patients who had gastrectomy or malabsorption history. Patients who remain deficient or insufficient on such doses need to be treated with hydroxylated vitamin D metabolites, since they are more readily absorbed than with ordinary sun or sun camp exposure. All patients should maintain a daily calcium intake of at least $1000 \mathrm{mg}$ (for ages 31 to 50 years) to $1200 \mathrm{mg}$ (for ages 51 and older) per day [44].

\section{Vitamin D Toxicity}

Vitamin D as a fat-soluble vitamin raised concerns about toxicity from excessive supplementation. Widespread vitamin D fortification of foods and drinks from the 1930s to 1950s in the United States 
and Europe led to reported cases of toxicity [45]. Hypercalcemia is responsible for producing most of the symptoms of vitamin D toxicity. Early symptoms of vitamin D toxicity include gastrointestinal disorders like anorexia, diarrhea, constipation, nausea, and vomiting. Bone pain, drowsiness, continuous headaches, irregular heartbeat, loss of appetite, muscle and joint pain are other symptoms that are likely to appear within a few days or weeks; frequent urination, especially at night, excessive thirst, weakness, nervousness and itching; kidney stones [46].

There are three major hypotheses for vitamin D toxicity [47]:

(i) Raised plasma $1,25[\mathrm{OH}] \mathrm{D}$ concentrations lead to increased intracellular $1,24[\mathrm{OH}] \mathrm{D}$ concentrations. This hypothesis is not widely supported as many studies revealed that vitamin D toxicity is associated with normal or marginally elevated $1,25[\mathrm{OH}] \mathrm{D}$ [23]. It was only Mawer et al. who reported elevated 1,25[OH]D with vitamin D toxicity [48].

(ii) Vitamin D intake raises plasma 25[OH]D levels to concentrations that exceed DBP binding capacity, and free 25[OH]D has direct effects on gene expression once it enters target cells. High dietary vitamin D intake alone increases plasma 25[OH]D. The low affinity of $1,25[\mathrm{OH}] \mathrm{D}$ for the transport protein DBP and its high affinity for VDR dominate normal physiology. This makes it the only ligand with access to the transcriptional signal transduction machinery. However, in vitamin D intoxication, overloading by various vitamin D metabolites significantly compromises the capacity of the DBP by allowing other metabolites to enter the cell nucleus. Of all the inactive metabolites, $25[\mathrm{OH}] \mathrm{D}$ has the strongest affinity for the VDR, and thus at sufficiently high concentrations, could stimulate transcription [47].

(iii) Vitamin D intake raises the concentrations of many vitamin D metabolites, including vitamin D itself and $25[\mathrm{OH}] \mathrm{D}$, and these concentrations exceed the DBP binding capacity and release of "free" $1,25[\mathrm{OH}] \mathrm{D}$ which enters target cells [47].

The amount of UVB radiation required for vitamin D sufficiency can be calculated from the amount of vitamin D produced from one minimal erythemal dose (MED), or 10,000-25,000 IU of oral vitamin $\mathrm{D}$ [9].The MED can be defined as the amount of time needed to cause skin to turn pink. The length of time varies with geographical location, skin pigmentation, percent of body fat, and age. Excessive exposure to sunlight will not cause vitamin D intoxication because sunlight degrades any excess vitamin D [48].

The highest recorded individual serum 25[OH]D concentration obtained from sunshine was from a farmer in Puerto Rico with a level of $225 \mathrm{nmol} / \mathrm{L}$ [49]. On the other hand, the highest recorded individual 25[OH]D achieved from artificial ultraviolet light treatment sessions was $275 \mathrm{nmol} / \mathrm{L}$ [50]. Vieth reported that vitamin $\mathrm{D}$ toxicity probably begins to occur after chronic consumption of approximately 40,000 IU/day (100 of the 400 IU capsules) [6]. Reports in which pharmacologic doses of vitamin D were given for a prolonged time, the indications why it was given and in which the final serum 25[OH]D concentrations are provided and summarized in Table 6.

\section{Hypersensitivity to Vitamin D}

Vitamin D hypersensitivity syndromes are often mistaken for vitamin D toxicity. The most common is primary hyperparathyroidism. Granulomatous diseases, such as sarcoidosis, granulomatous TB and 
some cancers also cause vitamin D hypersensitivity, as the granuloma or the tumor may make excessive amounts of calcitriol, thus raising serum calcium levels [6].

Table 6. Studies reporting elevated vitamin D status and associated diseases.

\begin{tabular}{|c|c|c|c|}
\hline $\begin{array}{c}\text { Reference, year, and daily } \\
\text { dosage }(\mu \mathrm{g})\end{array}$ & Duration & $\begin{array}{c}\text { Final } 25[\mathrm{OH}] \mathrm{D} \\
\text { concentration }(\mathrm{nmoL} / \mathrm{L})\end{array}$ & Indication \\
\hline Mason et al., [51], 19801250 & $>52$ weeks & 717 & Hypoparathyroidism \\
\hline $\begin{array}{c}\text { Haddock et al., [49], } \\
19821875\end{array}$ & $>100$ weeks & 1707.5 & Hypoparathyroidism \\
\hline $\begin{array}{l}\text { Gertner and Domenech [52], } \\
1977500-2000\end{array}$ & $12-52$ weeks & $442-1022$ & Various \\
\hline $\begin{array}{c}\text { Counts et al., [53], } \\
19752500\end{array}$ & 12 weeks & 1550 & Anephric \\
\hline $\begin{array}{l}\text { Hughes et al., [25], } 1976 \\
\quad 2500-6250 n=3\end{array}$ & $>52$ weeks & $1000-1600$ & Not stated \\
\hline $\begin{array}{c}\text { Streck et al., [54], } \\
19792500\end{array}$ & 3.8 years & 707.5 & Hypoparathyroidism \\
\hline \multicolumn{4}{|l|}{ Davies and Adams [55], 1978} \\
\hline 3750 & 364 weeks & 1125 & Paget disease \\
\hline 2500 & 520 weeks & 1000 & Thyroidectomy \\
\hline Mawer et al., [48], 1985 & & & Hypoparathyroidism \\
\hline 1875 & 520 weeks & 568 & Hypophosphatemic \\
\hline 5000 & 520 weeks & 1720 & rickets \\
\hline 2500 & 520 weeks & 995 & Carpal tunnel \\
\hline 1250 & 1248 weeks & 632 & syndrome \\
\hline 4285 & 26 weeks & 908 & Celiac disease \\
\hline 2500 & 520 weeks & 856 & Chilblain \\
\hline 2500 & 312 weeks & 778 & Thyroidectomy \\
\hline 1250 & 1040 weeks & 903 & $\begin{array}{c}\text { Arthritis } \\
\text { Hypoparathyroidism }\end{array}$ \\
\hline \multicolumn{4}{|l|}{ Allen and Skah [56], 1992} \\
\hline 1875 & 19 years & 267 & Hypoparathyroidism \\
\hline \multicolumn{4}{|l|}{ Rizzoli et al., [57], 1994} \\
\hline 15,000 & 96 weeks & 221 & \\
\hline 7500 & 3 weeks & 801 & Osteoporosis \\
\hline 7500 & 74 weeks & 1692 & Osteoporosis \\
\hline 1075 & 12 weeks & 374 & Hypoparathyroidism \\
\hline 7500 & 4 weeks & 650 & Osteoporosis \\
\hline 7500 & 4 weeks & 621 & Osteoporosis \\
\hline 250 & 390 weeks & 608 & Osteomalacia \\
\hline $\begin{array}{c}\text { Pettifor } \text { et al., [58] } 1995 \\
50,000(n=11)\end{array}$ & 10 days & $847-1652$ & Not stated \\
\hline $\begin{array}{c}\text { Jacobus et al., }[59] 1992 \\
725-4364(n=8)\end{array}$ & 6 years & "mean" 731 & Not stated \\
\hline
\end{tabular}




\section{Conclusions}

The present review discussed current knowledge on vitamin D physiology, its clinical relevance and evidence-based treatment options on vitamin D status correction. Caution should still be practiced by clinicians in providing vitamin D supplementation among vitamin D deficient populations, with proper monitoring using approved and certified methods. Indications for vitamin D supplementation outside the conventional calcium homeostasis should also be considered to maximize extra-skeletal benefits of vitamin D correction.

\section{Conflicts of Interest}

The authors declare no conflict of interest.

\section{References}

1. DeLuca, H. Overview of General physiological tenures and function of vitamin D. Am. J. Clin. Nutr. 2004, 80, 16895-16965.

2. Mawer, E.B.; Hayes, M.E.; Heys, S.E.; Davies, M.; White, A.; Stewart, M.F.; Smith, G.N. Constitutive synthesis of 1,25 dihydroxy vitamin $\mathrm{D}_{3}$ by a human small cell lung cancer cell line. J. Clin. Endocrinol. Metab. 1994, 79, 554-560.

3. Schwartz, G.G.; Whitlutch, L.W.; Chen, T.C.; Lokeshwar, B.L.; Holick, M.F. Human prostate cells synthesize 1,25 dihydroxyvitamin $\mathrm{D}_{3}$. Cancer Epidemiol. Biomark. Prev. 1998, 7, 391-395.

4. Holick, M.F. Sunlight, vitamin D and health: A D-lightful story. Nor. Acad. Sci. Lett. 2008, 2008, 147-166.

5. Jones, G.; Strugnell, S.; DeLuca, H.F. Current understanding of the molecular action of vitamin D. Physiol. Rev. 1998, 78, 1193-1231.

6. Vieth, R. Vitamin D supplementation, 25 hydroxy-vitamin D concentrations, and safety. Am. J. Clin. Nutr. 1999, 69, 842-856.

7. Ahmed, M.S.; Shoker, A. Vitamin D metabolites; protective versus toxic properties: Molecular and cellular perspectives. Nephrol. Rev. 2010, 2, 19-26.

8. Holick, M.F. High prevalence of vitamin D inadequacy and implications for health. Mayo Clin. Proc. 2006, 81, 353-373.

9. Holick, M.F. Sunlight and vitamin D for bone health and prevention of autoimmune diseases, cancers and cardiovascular disease. Am. J. Clin. Nutr. 2004, 80, 1678S-1688S.

10. Holick, M.F. Vitamin D: the underappreciated D-lightful hormone that is important for skeletal and cellular health. Curr. Opin. Endocrinol. Diabetes 2002, 9, 87-98.

11. Heaney, R.P.; Dowell, M.S.; Hale, C.A.; Bendich, A. Calcium absorption varies within the reference range for serum 25-hydroxyvitamin D. J. Am. Coll. Nutr. 2003, 22, 142-146.

12. Bischoff-Ferrari, H.A.; Dietrich, T.; Orav, E.J.; Hu, F.B.; Zhang, Y.; Karlson, E.W.; Dawson-Hughes, E.B. Higher 25 hydroxy-vitamin D concentration are associated with better lower-extremity function in both active and inactive persons aged $>60 \mathrm{yrs}$. Am. J. Clin. Nutr. 2004, 80, 752-758.

13. Holick, M.F. Vitamin D deficiency. N. Engl. J. Med. 2007, 357, 266-281. 
14. Cannell, J.J.; Hollis, B.W.; Zasloff, M.; Heaney, R.P. Diagnosis and treatment of vitamin D deficiency. Expert Opin. Pharmacother. 2008, 9, 107-118.

15. Lips, P. Vitamin D deficiency of secondary hyperparathyroidism in the elderly: Consequences for bone loss and fractures and therapeutic implications. Endocr. Rev. 2001, 22, 477-501.

16. Chapuy, M.C.; Preziosi, P.; Maamer, M.; Arnaud, S.; Galan, P.; Hercberg, S.; Meunier, P.J.; Prevalence of vitamin D insufficiency in an adult normal population. Osteopros. Int. 1997, 7 , 439-443.

17. Holick, M.F.; Siris, E.S.; Binkley, N.; Beard, M.K.; Khan, A.; Katzer, J.T.; Petruschke, R.A.; Chen, E.; de Papp, A.E. Prevalence of vitamin D inadequacy among postmenopausal North American women receiving osteoporosis therapy. J. Clin. Endocrinol. Metab. 2005, 90, 3215-3224.

18. Heaney, P.R. Functional indices of vitamin D status and ramifications of vitamin D deficiency. Am. J. Clin. Nutr. 2004, 80, 1706S-1709S.

19. Hanley, D.A.; Davison, K.S. Vitamin D insufficiency in North America. J. Nutr. 2005, 135, 332-337.

20. Hollis, B.W.; Wagner, C.L. Assessment of dietary vitamin D requirements during pregnancy and lactation. Am. J. Clin. Nutr. 2004, 79, 717-726.

21. Rajasree, S.; Rajpal, K.; Kartha, C.C.; Sarma, P.S.; Kutty, V.R.; Iyer, C.S.; Girija, G. Serum 25-dihyroxyvitamin $\mathrm{D}_{3}$ levels are elevated in South Indian patients with ischemic heart disease. Eur. J. Epidemiol. 2001, 17, 567-571.

22. Wang, T.J.; Pencina, M.J.; Booth, S.L.; Jacques, P.F.; Ingelsson, E.; Lanier, K.; Benjamin, E.J.; DÁgostino, R.B.; Wolf, M.; Vasan, R.S. Vitamin D deficiency and risk of cardiovascular disease. Circulation 2008, 117, 503-511.

23. Shepard, M.R.; Deluca, H.F. Plasma concentrations of vitamin $\mathrm{D}_{3}$ and its metabolites in the rat as infused by vitamin $\mathrm{D}_{3}$ intake. Arch. Biochem. Biophys. 1980, 202, 43-53.

24. Paulovitch, H.; Gurabedian, M.; Bulsan, S. Calcium mobilizing effect of large doses of 25-dyroxycalciferol ion anephric rats. J. Clin. Investig. 1973, 52, 2656-2659.

25. Hughes, M.R.; Baylink, D.J.; Jones, P.J.; Haussler, M.R. Radioligand receptor assay for 25-hydroxvitamin $\mathrm{D}_{2} / \mathrm{D}_{3}$ and 1 alpha,25-hydroxyvitamin. J. Clin. Investig. 1976, 58, 61-70.

26. Trang, H.M.; Cole, D.E.; Rubin, L.A.; Pierratos, A.; Siu, S.; Vieth, R. Evidence that vitamin $\mathrm{D}_{3}$ increases serum 25-hydroxyvitamin $\mathrm{D}$ more efficiently than does vitamin $\mathrm{D}_{2}$. Am. J. Clin. Nutr. 1998, 68, 854-858.

27. Armas, L.A.; Hollis, B.W.; Heaney, R.P. Vitamin $\mathrm{D}_{2}$ is much less effective than vitamin $\mathrm{D}_{3}$ in humans. J. Clin. Endocrinol. Metab. 2004, 89, 5387-5391.

28. Holick, M.F.; Biancuzzo, R.M.; Chen, T.C.; Klein, E.K.; Young, A.; Bibuld, D.; Reitz, R.; Salameh, W.; Ameri, A.; Tannenbaum, A.D. Vitamin $\mathrm{D}_{2}$ is as effective as vitamin $\mathrm{D}_{3}$ in maintaining circulating concentrations of 25-hydroxyvitamin D. J. Clin. Endocrinol. Metab. 2008, 93, 677-681.

29. Glendenning, P.; Chew, G.T.; Seymour, M.J.; Goldswain, P.R.; Inderjeeth, C.A.; Vasikaran, S.D.; Toronto, M.; Musk, A.A.; Fraser, W.D. Serum 25 hydroxyvitamin D levels in vitamin D insufficient hip fracture patients after supplementation wit ergocalciferol and cholecalciferol. Bone 2009, 45, 870-875. 
30. Gordon, C.M.; Williams, A.L.; Feldman, H.A.; May, J.; Sinclair, L.; Vasquez, A.; Coz, J.E. Treatment of hypovitaminosis D in infants and toddlers. J. Clin. Endocrinol. Metab. 2008, 93, 2716-2721.

31. Biancuzzo, R.M.; Young, A.; Bibuld, D.; Cai, M.H.; Winter, M.R.; Klein, E.K.; Ameri, A.; Reitz, R.; Salameh, W.; Chen, T.C.; et al. Fortification of orange juice with vitamin $\mathrm{D}_{2}$ or vitamin $\mathrm{D}_{3}$ is as effective as an oral supplement in maintaining vitamin $\mathrm{D}$ status in an adult. Am. J. Clin. Nutr. 2010, 91, 162-166.

32. Chan, J. Vitamin D update for nutrition professionals. Veget. Nutr. 2009, 18, 1-2.

33. Houghton, A.L.; Vieth, R. The case against ergocalciferol (vitamin $\mathrm{D}_{2}$ as a vitamin supplement). Am. J. Clin. Nutr. 2006, 84, 694-697.

34. Hollis, B.W. Comparison of equilibrium and disequilibrium assay conditions of ergocalciferol and cholicalciferol and their metabolites. J. Steroid Biochem. 1989, 21, 81-86.

35. Horst, R.L.; Reinhardt, T.A.; Ramberg, C.F.; Koszewski, N.J.; Napoli, J.L. 24-Hydroxylation of 1,25-dihydroxyergocalciferol: An unambiguous deactivation process. J. Biol. Chem. 1986, 261, 9250-9256.

36. Jones, G. Analog Metabolism in Vitamin D; Feldman, D., Glorieux, F., Pike, J.W., Eds.; Elsevier Academic Press: Melville, NY, USA, 1997; pp. 73-94.

37. Institute of Medicine Standing Committee on the Scientific Evaluation of Dietary Reference Intakes. Dietary Reference Intakes for Calcium, Phosphorus, Magnesium, Vitamin D, and Fluoride; National Academy Press: Washington, DC, USA, 1997.

38. Teresa, K.; Amy, G.; Jackie, R.; Jennie, H.; Sarina, S. Vitamin D: An evidence based review. J. Am. Board. Fam. Med. 2009, 22, 698-706.

39. Hanley, D.A.; Cranney, A.; Jones, G.; Whiting, S.J.; Leslie, W.D. Guidelines Committee of the Scientific Advisory Council of Osteoporosis of Canada. Vitamin D in adult health and disease; a review and guideline statement from Osteoporosis Canada (summary). Can. Med. Assoc. J. 2010, 182, 1315-1319.

40. Dawson-Hughes, B. Treatment of Vitamin D Deficient States, 2010. Wolters Kluwer Health Website. Available online: http://www.update.com/contents/treatment-of-vitamin-d-deficiency-inadults (accessed on 11 September 2013).

41. Vieth, R. Critique of the consideration for establishing the tolerable upper intake level for vitamin D: Critical need for revision upwards. J. Nutr. 2006, 136, 1117-1122.

42. Dawson-Hughes, B.; Heaney, R.P.; Holick, M.F.; Lips, P.; Meunier, P.J.; Vieth, R. Estimates of optimal vitamin D status. Osteoporos. Int. 2005, 16, 713-716.

43. De Torrente de la Jara, G.; Pecoud, A.; Favrat, B. Female asylum seekers with musculoskeletal pain; the importance of diagnosis and treatment of hypovitaminosis D. BMC Fam. Pract. 2006, 7, 4.

44. Institute of Medicine (US) Standing Committee on the Scientific Evaluation of Dietary Reference Intakes. Dietary Reference Intakes for Calcium, Phosphorus, Magnesium, Vitamin D, and Fluoride; National Academies Press: Washington, DC, USA, 1997.

45. Holick, M.F. Vitamin D deficiency: What a pain it is. Mayo Clin. Proc. 2003, 78, 1457-1459.

46. Schwalfenberg, G. Not enough vitamin D: health consequences for Canadians. Can. Fam. Phys. 2007, 53, 841-854.

47. Jones, G. Pharmacokinetics of vitamin D toxicity. Am. J. Clin. Nutr. 2008, 88, 5825-5865. 
48. Mawer, E.B.; Hann, J.T.; Berr, J.L.; Davies, M. Vitamin D metabolism in patients intoxicated with ergocalciferol. Clin. Sci. (Lond.) 1985, 68, 135-141.

49. Haddock, L.; Corcino, J.; Vazquez, M.D. 25 OHD serum level in the normal Puerto Rican population and in subject with tropical sprue and parathyroid disease. Puerto Rico Health Sci. J. 1982, 1, 85-91.

50. Krause, R.; Buhring, M.; Hopfenmuller, W.; Holick, M.F.; Sharma, A.M. Ultraviolet B and blood pressure. Lancet 1998, 352, 709-710.

51. Mason, R.S.; Lissner, D.; Grunstein, H.S.; Posen, S. A simplified assay for dihydroxylated vitamin D metabolites in human serum: Application to hyper- and hypovitaminosis D. Clin. Chem. 1980, 26, 444-450.

52. Gertner, J.M.; Domenech, M. 25-Hydroxyvitamin D levels in patients treated with high-dosage ergo- and cholecalciferol. Clin. Pathol. 1977, 30, 144-150.

53. Counts, S.J.; Baylink, D.J.; Shen, F.H.; Sherrard, D.J.; Hickman, R.O. Vitamin D intoxication in an anephric child. Ann. Intern. Med. 1975, 82, 196-200.

54. Streck, W.F.; Waterhouse, C.; Haddad, J.G. Glucocorticoid effects in vitamin D intoxication. Arch. Intern. Med. 1979, 139, 974-977.

55. Davies, M.; Adams, P.H. The continuing risk of vitamin-D intoxication. Lancet 1978, 2, 621-623.

56. Allen, S.H.; Shah, J.H. Calcinosis and metastatic calcification due to vitamin D intoxication. A case report and review. Horm. Res. 1992, 37, 68-77.

57. Rizzoli, R.; Stoermann, C.; Ammann, P.; Bonjour, J.P. Hypercalcemia and hyperosteolysis in vitamin D intoxication: Effects of clodronate therapy. Bone 1994, 15, 193-198.

58. Pettifor, J.M.; Bikle, D.D.; Cavaleros, M.; Zachen, D.; Kamdar, M.C.; Ross, F.P. Serum levels of free 1,25-dihydroxyvitamin D in vitamin D toxicity. Ann. Intern. Med. 1995, 122, 511-513.

59. Jacobus, C.H.; Holick, M.F.; Shao, Q.; Chen, T.C.; Holm, I.A.; Kolodny, J.M.; Fuleihan, G.E.; Seely, E.W. Hypervitaminosis D associated with drinking milk. N. Engl. J. Med. 1992, $326,1173-1177$.

(C) 2013 by the authors; licensee MDPI, Basel, Switzerland. This article is an open access article distributed under the terms and conditions of the Creative Commons Attribution license (http://creativecommons.org/licenses/by/3.0/). 